\title{
Rolling back Modernity: Selective Tradition and Contemporary Literary Politics in the South Pacific
}

\author{
JENNIFER LAWN
}

\begin{abstract}
This article relates Raymond Williams's concept of "selective tradition" to the shaping of literary history in Aotearoa New Zealand. It makes the case for the ongoing salience of Williams's narrative of modernity as a "long revolution," and his sense of the threats to democratic and cultural participation around the turn of the 21 st century, as a framework for situating recent cultural politics. The article closes with some suggestions for possible future directions for the development of locally-based materialist literary criticism.
\end{abstract}

It is a delight to be invited to speak at the Wellington conference of the Raymond Williams Society of Japan on the topic of "Selective Tradition in the South Pacific." It is a pleasure to be introduced to a close-knit group of Williams scholars who are carrying forward his mission and lifework, but grappling with Williams's monumental oeuvre is also a humbling task. I must also admit to feeling slightly out of place at a conference that focuses on socialist politics. If I had to declare my political commitments, then "social democrat" would come closest-a political allegiance which Williams himself derided as "an amazing and implausible mix of patriotism, internationalism and social justice." I am a union member, of the kind who wonders from time to time whether I would be better off investing the membership fees in my Kiwisaver account. The last public protest I took part in was some years ago, when I joined thousands of cyclists to take over the Auckland harbour bridge-definitely a high point for the lycra-clad crowd, but not much of a blow for the social underdog. I'm from a firmly middle-class background, and feel particularly aware, here in Williams's abiding intellectual presence, of the privileged and sometimes self-congratulatory mind-set that this social position brings with it.

But like many people in Aotearoa New Zealand, I have watched political developments with dismay, at both a global and local level. A revolutionary moment, as Conor Gearty suggests, occurs "when decisions are taken regardless of economic, institutional, social, or cultural consequences." ${ }^{2}$ We seem to be in such a moment now, with a sense of abandonment of reason and recklessness toward the future. Most blatantly, the United States is led by a compulsivelylying President who has little concept of constitutional process and insinuates the language and forms of fascism. The excesses and nepotism of Trump's regime have been likened to the Tudor court and imperial Rome, and the situation has deteriorated to the point where commentators are debating whether the United States counts as a failed state and whether Trump is actually mad, or merely pretending to be mad. But the broader fear is that Trumpism is a symptom of a wider cancer, one that would not be rooted out merely by a change of administration in the United States. Europe, which might otherwise provide a cornerstone for ideals of cosmopolitanism and worker rights, is breaking apart through renewed bouts of nationalism and protectionism. Japan, too, has an oppressively nationalist leadership under Shinzo Abe, and leaders in the tenuous democracies of Southeast Asia are taking strength from the authoritarian lead in the White House. Certainly the rash of articles, newspaper headlines and books with alarmist titles - "Britain Prepares to Leave the World," "Is This How Democracy Ends," "A New Dark Age," How Democracies Die, to give some representative examplesshows a wave of anxiety among left-oriented commentators in Anglophone democratic states. 
By comparison with world events, the bland, compromised centrism of New Zealand's political culture might seem positively welcome. After all, we have Jacinda in power, dubbed the "antiTrump" by Vogue magazine! ${ }^{3}$ But New Zealand, too, has its moments of historical rupture and slow crisis-and one of the challenges in a settler-colonial state is the difficulty of understanding what counts as rupture and crisis, how, when, and for whom. In line with other economies in the Anglophone world, New Zealand has seen a rise in income disparity over recent decades, stagnation in real wages, transfer of debt from corporations and the state to households and students, entrenched rates of poverty, and high rates of imprisonment, especially for Māori-underpinned by a strikingly low popular acceptance of the view that it is the state's role to provide for equitable distribution of resources. ${ }^{4}$ In a quieter but persistent way, the misuse of state authority, and the negative social consequences of privatization, also infect our country.

The ground note for my discussion today is Williams's early work The Long Revolution (1961), in which he traces the process of England's centuries-long "cultural revolution": an incremental expansion and inclusiveness in the communicative capacities of "culture" in a broad sense, from literacy to formal education and public access to an increasingly broad range of materials and ideas. In decidedly non-alarmist, mediatory terms, Williams sets localised setbacks in the democratisation of culture within a much longer, gradualist trajectory: this is a "genuine revolution, transforming men and institutions; continually extended and deepened by the actions of millions, continually and variously opposed by explicit reaction and by the pressure of habitual forms and ideas." Though Williams does not specifically argue the case in this work, The Long Revolution offers a counterpoint to other metanarratives of modernity that see revolution in terms of crisis and rupture: whether the rupture of popular revolution as an overturning of an entrenched political and social order and the establishment of a republican state; or the repeated revolutions, or cycles, of predatory forms of capital which undergo phases of incursion into new territories and expansion into newly-created markets.

I am a literary critic, with a specialisation in contemporary New Zealand fiction and recent literary history - a niche area, relative to Williams's synthesising scope. My most recent projects have been based around trying to understand more about how New Zealand authors imagine social class in their fiction, and how they comment on contemporary economic life, social patterns and politics. The backdrop for this work consists of the twin moments of rupture that have shaped the last fifty years of literary politics in this country: the progressivist movements of the 1960s, in the form of the Māori renaissance, second-wave feminism, and the counterculture; and the economic reforms of the post-1984 neoliberal era. My discussion today is based on the view that, in any effort to widen the base for materialist analysis in this country, and to inspire a cultural practice that supports the work of the long revolution, Williams's work remains a signal reference point.

\section{Long Revolution, Slow Crisis: Unwinding Modernity}

In 1961, Raymond Williams published his vision of what he termed the "long revolution," the moulding of a new social order through the slow and difficult working-out of a fundamental human drive to remake ourselves and our environment. This flourishing of human potential develops through three intertwined processes: industrial and technological innovation; the rapid rise of literacy, public culture and mass culture; and democratic participation: "the rising determination, almost everywhere, that people should govern themselves, without concession of this right to any particular group, nationality or class." ${ }^{\circ}$ The long revolution is an incremental process carried through by human effort; it is cultivated by the myriad processes of "open discussion, extending relationships, the practical shaping of institutions." "England's "cultural 
revolution" was an integral driver of the process, not subordinate to economic or political forces. Williams maintained this position consistently, even against attacks from more determinist colleagues, as he restated it later in his career: "the steam press [and its subsequent expansion of literacy] was as much a part of the industrial revolution as the steam jenny or the steam locomotive." 8

Williams's understanding of the term "culture" is notoriously broad and synthesising, though always turned strategically toward the dignity and participation of the broadest base of society. In the Long Revolution, he writes of the two poles of culture-art, or culture as aesthetic practice, and lived experience, or culture as a whole way of life-pulling together towards the collective ends of the long revolution. Art is a highlighted case of a more general productive capability. We create "our human world as we have thought of art being created," he wrote, borrowing from contemporary developments in cognitive psychology. But as art becomes ordinary, daily life becomes extraordinary: "art is ratified, in the end, by the fact of creativity in all our living." Culture, in the end, becomes a sweeping category that encompasses "everything we see and do, [as] the whole structure of our relationships and institutions, depends, finally, on an effort of learning, description and communication." 10 To progress the long revolution forward toward a socialist horizon, we have to constantly look backwards: we shape the future by shaping the past. Tradition becomes a "work of conscious reconstruction" which is "not only a selection but also an interpretation." "This is the work of selective tradition, which Williams regards as a creative, responsible and necessary act.

Williams ends The Long Revolution with a caution: looking ahead to Britain in the sixties, he sees flashes of danger that threaten to stall or derail the long revolution. Britain's power was waning through global industrial competition and decolonisation, and Williams believed that the nation was reacting to the new global realities in destructive ways. There was a growing resistance to central planning, and power was passing to financial institutions and selffinancing corporations. The understanding of class consciousness had degraded into a confused and politically ineffective category through the co-option of union leaders and a muddled, disempowering concept of social class. "It is the reality of differential treatment, rather than the particular forms through which it operates, that makes a class system," he wrote; and "the growing feeling that class is out of date and doesn't matter is being used to ratify a social system which ... is still essentially based on economic classes." 12 Without constant efforts to keep reinforcing democratic processes, the long revolution can turn toward a gathering crisis. By the time of his publication Towards 2000 (1983), Williams is even less sanguine, and his sense of disappointment now extends to the cultural dimensions of the long revolution as well as its economic and political drivers. Democratic participation was retreating through the selfserving interests of the political elite and an archaic voting system (Williams advocated a form of proportional representation), along with a significant reduction of "the existing organisations and expectations of wage-earners" and "decimation of British industrial capital itself." "In the sphere of culture, artistic attacks on bourgeois society earlier in the century had become commodified and rerouted into a dismissal of ordinary people as "mass society," leading to "the long and bitter impasses of a once liberating modernism."14 In the economic sphere, the imperative of competition at all costs was coming to dominate all other values. The sense of the future, so important as a horizon for action, had been captured and truncated by a group that Williams called "Plan X people." Anticipating that the future would bring a decline in capitalist profitability, Plan X people narrow their sights to a relentless and bitter struggle for competitive advantage, "a phase at a time, a decade at a time, a generation at a time." 15 In their drive to press through their vision of the future, Plan X people "resemble the hardest kinds of revolutionary," but with no corresponding vision of a transformed society: "no new order, no 
lasting liberation seriously enters these new calculations, though their rhetoric may be retained." 16 Instead, "as the margins narrow," the always-present threat of a turn towards authoritarianism gathers force, "confining and if necessary getting rid of any substantial democracy." 17 Just as it develops incrementally, the long revolution can be gradually undermined by the corrosive dynamic that Williams termed the "constitutional authoritarianism" of Thatcherism: the cynical and self-interested capture of decision-making processes within a moribund political system.

Born in 1921, Williams had lived and flourished across social worlds, from the Welsh mining valleys of his childhood to the class-bound halls of Cambridge. He had benefited from a period of social mobility and access to higher education that he himself termed "a quarter of a century of both real and manufactured expectations." 18 These middle decades of the twentieth century were based on an unprecedented (and ultimately unsustained) compromise between capital and labour that, in retrospective analysis, had as much to do with the measures necessary to steer Western economies through two world wars as with any historically enduring shift in commitment to comprehensive welfare. ${ }^{19}$ In an interview with Terry Eagleton in 1987, Williams declared himself disappointed, but not disillusioned, as he argued for a refocusing of leftist politics to counter new forms of exploitation and social enclosure. ${ }^{20}$

Three decades later, the three interlaced elements of the long revolution all seem in further retreat. In the political sphere, authoritarian populism is rising in the United States, the United Kingdom, and Central Europe, and formal democracy is now in decline globally. In terms of economic forces, neoliberalism's fundamental tension between the vaunted transparency of market processes and its punitive class politics has ruptured, as the working class assert a politically and morally powerful voice as the neglected "losers" of globalisation and automation. ${ }^{21}$ And the incremental "cultural revolution" that Williams tracked through a broadening of formal education and communicative capabilities has become mired in post-truth politics. Suddenly all of those institutions of modernity that were the subject of critique in the 1990s by critical theorists in academia - truth, the bourgeois public sphere, cosmopolitanism, liberalism, discourses of individual rights, citizenship, and even civility — seem desperately in need of resurrection.

\section{Selective Tradition and Narratives of New Zealand Literary History}

Here in a South Pacific context, what phases of historical action count as revolution and crisis, and for whom? Whose timeframe defines modernity, who is included or excluded within the ameliorative story of the long revolution, whose tradition is at stake? Why refer to Williams at all here in Aotearoa New Zealand, given that his foundational and most widely-read works deal with British literature and institutions, with little detailed analysis of the forces of empire? ${ }^{22}$

It is not that the idea of selective tradition is irrelevant, here and now, over half a century after Williams's early uses of the idea. It's rather that the idea has become absorbed so widely that it has become ingrained into a postcolonising literary imagination. Williams's fate, in this regard, is to have become part of the intellectual wallpaper of late-twentieth-century cultural politics. Here is Williams's restatement of the idea of selective tradition in 1966:

A tradition is not the past, but an interpretation of the past: a selection and valuation of ancestors, rather than a neutral record. And if this is so, the present, at any time, is a factor in the selection and valuation. It is not the contrast but the relationship between modern and traditional that concerns the cultural historian. ${ }^{23}$

"Selective tradition" is a benign way to describe what, for indigenous peoples, has been a matter of survival, as they adopt what is useful and necessary from European technologies, and 
maintain or reactivate lines of tradition and custom that ensure genealogical and cultural survival. Māori writing in English - the "profane" language, as Witi Ihimaera calls it —weaves traditions together, as Māori authors appropriate Western literary genres and traditions as vehicles for indigenous ways of being and knowing. ${ }^{24}$ More recently, Māori writers have realigned lines of influence and heritage to focus on Oceanic and trans-Indigenous alliances. Across the wider field of Māori, Pākehā, and migrant writing, the work of selective tradition underlies the incredible flourishing of historical fiction in both literary and popular modes. Eurocentric narratives of the past have been reworked to integrate multiple points of view. Early contact is no longer depicted in terms of myths of European discovery, but rather in terms of a "contact zone" of mutual discovery, intermingling, mobility, and multilateral lines of power between Māori and European voyagers. Depictions of the colonial era now downplay settler pioneer destinies and British superiority, and foreground Māori struggle, resistance, and transition. The decades of settler cultural nationalism-when the towering presences of Sargeson, Curnow, and Brasch saw themselves as forging a distinctive, local voice- are now framed in terms of exclusionary self-mythologising, even as these authors continue to generate new readings and debates. This reopening and revaluation of history helps Pākehā, at least, to believe and prove that we can be better than our past. A more equitable future is imagined by reactivating history for present purposes, propelling the long revolution forward in its widest and most positive sense.

This emphasis on rewriting colonial and provincial history may produce another kind of blindspot, in the sense that scholars of literary fiction, at least, have had some difficulty in writing comprehensively of the contemporary moment and the recent past. There was a phase of literary criticism when readers of book-length surveys of New Zealand literature might be forgiven for believing that Māori literary tradition does not start until the late 1960s, while Pākehā literature stops somewhere around Janet Frame's 1988 novel The Carpathians. Perhaps most significant, given the focus at this conference on Raymond Williams, is the fact that relatively few literary historians or commentators debate New Zealand literature in terms of social class, class consciousness and social formation, whether in terms of the authors' life experience and political commitments, or representations of class in fictional worlds, or the infrastructure of publishing, marketing and teaching. The work of selective tradition, to return to Williams's understanding of the term, calls on us to embrace the "meanings ... that we feel and discover we need," including the "difficulties" as well as "the achieved meanings." Is a materialist approach such a difficulty? In 1991, Rachel Barrowman published a book called $A$ Popular Vision: The Arts and the Left in New Zealand 1930-1950. What would it look like to write a book with the title "the arts and the left in New Zealand," updated to writers of today? In partial answer to this question, in 2016 I published a study of fictional works by 14 Pākehā and Māori authors, titled Neoliberalism and Cultural Transition in New Zealand Literature, 1984-2008: Market Fictions. The central question was how recent fiction might be selected, valued and interpreted, if the considerations of economy, society, social class, and property were to be brought to the foreground. Unusually for a work of literary history, it is not divided into periods or genres, as the diversity and range of fiction that is now produced cannot easily be defined in terms of a dominant, historically specific "style." Instead, I selected fiction that was set between the election of the Lange-Douglas government in 1984 and the global financial crisis of 2008, tracing the reverberations of the reform years through subsequent decades. Novels and stories were included if they showed a concentration of interest on material life broadly defined: the grounds of everyday economic life, the nature of work from precarious labour to the creative economy, the ways in which communities constitute and sustain themselves, how property is valued and circulates, and the realization of selfdetermination as both a political and subjective capacity. What transpired is a body of work 
that shows a sense of foment around social and cultural change, with varying degrees of political mobilisation and formal avenues of expression, but little sense of a coherent political movement or tradition on the part of socialist (or left-oriented) writers.

Neoliberalism and Cultural Transition is not written in a personal voice but, perhaps like all academic work in the end, the project has personal origins in terms of my own family's experience. Via pathways of British colonial influence, my parents also benefitted from technological advances and social mobility through the post-war years, only to see what Williams refers to as a "hardening" of attitudes toward social competition in the neoliberal turn of the 1980s. My parents were both educators. Their parents and grandparents were farmers, shop assistants, miners, railway workers from London, Cornwall and Scotland - and the odd one out, my Welsh great-grandfather, who was an Anglican minister. My father was born in 1931, and so was too young to fight in World War II. Then three kids came along, all born in the 1960s. I sometimes picture my family as if in one of those cartoons where characters scramble across a bridge that is collapsing behind them. We were the last group to enjoy benefits such as the universal child benefit, wages for teachers that were on a par with other professionals, a generous government superannuation package for my father, relatively affordable housing, and free tertiary education. Culture, too, was subsidised and state sponsored. My parents made the rounds of professional theatre and the symphony, orchestra, and art society. By accessing middle-brow culture, they were showing a form of social competence, signalling ascendant class status and opening the right kinds of networks and relationships; but they were also owning and enjoying a genuinely new breadth of cultural experience. When Raymond Williams wrote in "Culture Is Ordinary" that "we live in an expanding culture, and all the elements in this culture are themselves expanding," what he described, at least in part, was this crosshatching of the popular into national culture, and the access of ordinary people to formerly élite, European-based forms of art. ${ }^{25}$

In their studies resulting from the Privilege Project initiative, Belinda Borell, Helen MoewakaBarnes and Tim McCreanor caution against stories of middle-class Pākehā who trumpet their family's working-class roots. ${ }^{26}$ Such stories can serve as a vehicle for the presumption of merit; they can also act as an implicit reproach against people who have failed to seize opportunities for self-improvement and hence do not deserve social sympathy or support. My point is somewhat the opposite: my family was boosted by state support, through a period that, for middle-class Pākehā at least, were decades of stable employment, access to tertiary education and a rapid rise in the standard of living. When economic reform arrived in the guise of Rogernomics, the impacts on my own family were mild. There were shake-ups in education; my father took early retirement through a restructuring of the special education service, and my mother resigned in protest against policy changes in the delivery of speech language therapy services. As the last one in my family to complete university courses in New Zealand, I saw my fees at the University of Otago rise one thousand percent from $\$ 150$ (for the compulsory student union fee) to around $\$ 1,500$ in 1990. Those in other sectorsmanufacturing, agriculture, meat processing - were not so insulated from the harshness and speed of economic reform.

This account of New Zealand's situation, with its focus on a legacy of social deficit, anxiety and debt relative to wealthier prior generations, is also not innocent. There is a risk of overstating the benevolence of the pre-1984 welfare state, and we don't want a regressive Pākehā nationalism that seeks to "make New Zealand great again." By the same token, there is also a risk of overemphasising Māori social deficit in recent decades, a narrative that both encumbers Māori with restrictive stereotypes and underplays their achievements, while 
obscuring negative social indicators in other ethnic groups that also need intervention. Neoliberalism rejected state protection, through top-down reform in the name of equality; authoritarianism, conversely, uses nostalgia for state protection from global market forces as a basis for top-down revolution in the name of the people. Neither of those pathways is exactly a positive future for Aotearoa New Zealand.

Turning to Williams's oeuvre to find a way forward is not an immediately obvious shift, given that his career-long emphasis on the need to forge a common culture seems out of step with the language of difference and identity that generates so much of cultural politics here; but for that very reason his particularly integrative and capacious account of the relationship between society and culture might challenge or extend the terms of local debates. "Like new ways of seeing, old ways must be actively learned," Williams wrote in The Long Revolution; ${ }^{27}$ so the archive of socialist thought may be reopened and debated with renewed urgency.

\section{Williams's Long Reach: Four Suggestions Toward a Local Materialist Critical Practice}

Thinking along the grain of some of Williams's foundational ideas, here are some observations and possible new pathways for literary criticism in Aotearoa New Zealand.

1. Williams's account of the "two faces of modernism" still retains some explanatory power in New Zealand cultural politics. The legacy of settler modernism is still casting a long shadow over cultural politics in New Zealand. Williams famously wrote of the "two faces of modernism," referring to the dual political impacts that aesthetic radicalism had in its historical moment, as opposed to its ongoing legacy. Modernism broke up the calcifications of bourgeois thought, but in its elevation of the artist as a breed apart from "mass man," it also fostered an elitist tendency to disparage the lives of ordinary people. By 1983, in Towards 2000, Williams saw modernism's reductive version of human existence as an anticipatory structure of feeling based in cynicism, which "hardened" into the formal institutions and policies of Thatcherism:

The originally precarious and often desperate images - typically of fragmentation, loss of identity, loss of the very grounds of human communication-have been transferred from the dynamic compositions of artists who had been, in majority, literally exiles, having little or no common ground with the societies in which they were stranded, to become, at an effective surface, a "modernist" and "post-modernist" establishment.... These forms which still claim the status of minority art have become the routine diversions and confirmations of paranational commodity exchange, with which indeed they have many structural tendencies. ${ }^{28}$

In terms of a character type, the modernist artist-hero can be seen as a precursor of Williams's "Plan X individual," a financial risk-taker who is numb to the potential stakes and consequences for ordinary people across entire economies. ${ }^{29}$ More recently, this figure of the singular, self-realising and self-expressive individual has been incorporated back into the sphere of artistic practice as a "creative entrepreneur" who is the (in reality, usually poorly paid) driver and exemplar of the "creative economy."

The historical trajectory that Williams traces also applies, broadly and persuasively, to the evolution of settler literary politics in this country. Mid-century realist writers depicted the figure of the little grey suburban (lower) middle-class man as the epitome of the bland, riskaverse New Zealand provincial imaginary; and where this figure drew a degree of sympathy and solidarity for a writer such as Bill Pearson, it also became the target of a young group of neoliberal reformers who saw their parents' generation as sedated by cradle-to-grave welfare 
and maladapted to the rigours of the free market. The landslide vote in favour of the Fourth Labour government in 1984 was more an indication that people were united in what they didn't want, as a rejection of narrow provincial values, rather than in a shared vision of the future. Vestiges of earlier egalitarian aspiration became stripped out as, in the years of policy reform that followed 1984, the punitive pole of the equation became intensely concentrated on beneficiaries and the working poor. But Williams's lesson for later generations is to be selfconscious and aware, not only of what we are rejecting in previous generations, but also of what we have absorbed. It is vital work to call the exponents of settler cultural nationalism to account for their sexism, homophobia and ethnocentric bias; but the task of critique is only partial if the (unintended) legacy of contempt for the dignity of ordinary people is not also addressed through the additional analysis of social class and economic inequalities.

2. It is time for realism (and some other, more critically neglected genres) to be redeemed as a form of social inquiry. One of the consequences of that "long shadow" of settler cultural nationalism has been a set of vexed and politically charged debates around the status of realism as a genre. The received story of genre in settler literary tradition, at least, is from a narrow prescription of realism opening out into an efflorescence of genre experimentation and plurality of voices by 1980s. For a small but highly influential coterie of male writers, a realism based in disappointment, muted feeling and confinement was both an aesthetic principle and a political morality. The narrowing of experience and lack of verbal pleasure in some of the more grinding fictions of mid-century realism was theorised at the time as a means to raise consciousness: through a first-person, naïve, and restricted point of view, the reader was meant to see and feel the desolation of provincial life. ${ }^{30}$

The historical record of publishing and reading was always more diverse than this narrow view allowed, but over the last fifty years there has been a flourishing of genres and styles, through widespread changes in cultural patterns and infrastructure: the proliferation of publishing channels; the breakdown of divisions between literary and popular styles; the survival of specialised genre publishers, both in New Zealand and offshore; the proliferation of young adult fiction in New Zealand, which draws on traditions of fantasy, speculative fiction, steampunk, and Gothic; the retrospective recasting of canonical works, now read through genre lenses such as Gothic, romance and melodrama; the weaving together of European and Polynesian traditions in much Māori fiction in English; and, in literary fiction more generally, a writerly grabbing of experiments in narrative structure and voice from the massive storehouse of modernism. ${ }^{31}$

This historical progress, from a narrowly prescribed form of realism to a plurality of genres, tends to be rehearsed (as I am doing now) to emphasise, and celebrate, the democratisation of voices and perspectives that it implies. But realism, too, has moved on since the days of Duggan, Shadbolt, Pearson, and early-career Gee. Like other genres, it has pluralised into "realisms" that call for new forms of critical emphasis and attention, and which are "not clearly or straightforwardly alignable with the realisms of previous literatures." ${ }^{32}$ In this view I am influenced by the editors of the essay collection Reading Capitalist Realism (2014), who specifically refute the suggestion, voiced most concisely by Fredric Jameson, that realism is "ontologically committed to the status quo as such." ${ }^{33}$ Instead they promote the genre that they term "capitalist realism." Like other forms of realism, capitalist realism "claims to explain the world around us" rather than transform registers of experience or transport the reader to alternative worlds; but the editors also argue that "capitalist realism need not only represent closure and defeat. It can also operate theoretically and critically to describe the relationship between accumulation and representation in the present." ${ }^{34}$ As Williams himself showed in his 
study of revolution and tragedy, genres are tools to think with and through. ${ }^{35}$ It also calls for a nonprogrammatic approach to genre, in contrast to the tendency in some critical traditions, including socialist thought, to designate some genres as inherently progressive, while condemning others tout court as politically compromised or reactionary irrespective of context or interpretative lens. To dismiss realism as mere content, or an objectionably masculine form, or in terms of a spurious claim to capture reality, would miss the subtleties and closelyobserved observations of social class and manner in writers as diverse as Charlotte Grimshaw, Alan Duff, Paula Morris, Damien Wilkins, and Maurice Gee.

I should add, in the further spirit of genre agnosticism, that the politics of popular genres are also underrealised in New Zealand. Local crime fiction has drawn very little critical attention, despite being intensely invested in place, the blurred borders of criminality and legality, and (with some exceptions) a comic good-humouredness. Williams in fact recoiled from crime and espionage stories on the basis that they "mediat[e] the deep assumptions of habitual competitive violence, deception and role-playing, loss of identity, and relationships as temporary and destructive," 36 but I would suggest that this negative impetus is being reworked - in the socially oriented crime fiction of Alix Bosco, for example, or the exposure of female vulnerability and desire in the work of Paddy Richardson. Local speculative fiction has followed international trends in a general shift from an earlier predominance of Utopia, from colonial times to the mid-twentieth century, declining towards a predominance of dystopia in more recent decades. Recent survey articles have promisingly set the groundwork for further development. ${ }^{37}$ With a focus on dystopia, Jack Ross suggests that "it wasn't really until the 1970s that the first genuinely unassimilable fictional texts started to appear here." Conversely, in his article "Rediscovering Utopia," Dougal McNeill traces the "drying up" of Utopia as a literary form in the middle decades of the twentieth century, and advocates, in the spirit of Williams, for the renewal of a more generalised "utopian impulse," a "drive for collectivity keeping itself alive and reappearing in unexpected places," which prompts us to "think on how such resolutions, in our own lives, might be achieved." 38

3. It has been difficult to write about social class in contemporary New Zealand literature for some decades, and for a number of reasons. The first stumbling block is no doubt conceptual. New Zealand has, at best, a patchy sociological literature on class, as Charles Crothers suggests in his survey of the field. ${ }^{39}$ The casualization of employment, the end of compulsory union membership, the rise of a white collar precariat, the marketing language of "tribes" based on consumer typologies, variable and unexpected identifications across socioeconomic groups (where South Aucklanders, for example, give their list vote to the National Party) - all have driven attempts to reconceptualise class-based groupings and affiliations. The second reason for the sidelining of class debate may well relate to middle-class biases in the institutional infrastructure of reading and publishing. Materialist literary theory is not strongly represented in university English programmes in this country; and in terms of the influence of cousin disciplines, I would suggest that history and anthropology have inflected local literary criticism rather more than sociological traditions. The third reason is ethical, and it relates to the class position of many of the people who publish literary commentary: it seems hypocritical for middle-class people to speak on behalf of the poor, and so we don't attempt to do so, while also failing to interrogate the specificity and normativeness of our own class position. Finally, there are various pitfalls of applying Western conceptions of class to Māori society. Traditional Māori were hierarchical but not divided into property-based groupings in the manner of classical sociological analysis. Sociologists such as Tracey McIntosh and Evan Te Ahu Poata Smith have written about Māori privilege and income gaps within Māoridom, while also maintaining the larger, much more insistent reality of Māori socioeconomic disadvantage in 
full sight. In the specific field of literary studies, however, Māori scholars who write about and publish Māori writing do not raise class as a primary factor in situating their field, or even see it as useful or relevant to the cause of decolonisation.

For these various reasons, I don't believe that there is a coherent equivalent of "working class studies" as has emerged in the United Kingdom and United States, and which is perhaps now in turn transmuting into studies of precarity, poverty and social abjection. ${ }^{40}$ For my own research, it has been a first step to analyse the representation of class in the social novel in New Zealand, defined as fiction that foregrounds and thematises exchanges between characters of distinctive social groups. In Neoliberalism and Cultural Transition, I found a common pattern across selected novels: Nigel Cox's Dirty Work, Maurice Gee's Crime Story, Anne Kennedy's The Last Days of the National Costume and Alix Bosco's Ann Markunas crime fiction. Middleor upper-class characters undergo a brief but traumatising encounter with working-class characters or representatives of a criminalised underclass. For all of the diverse styles of these texts, there was a commonly shared implication that although classes can intersect, they can't satisfactorily interact. While this kind of literary analysis draws out the intense class consciousness of some New Zealand writers, it situates marginalised people as the objects of a middle-class gaze, rather than representing themselves. A working-class literary archive remains to be selected and appreciated, to some extent within published work and also via other outlets that fall outside the relatively narrow pipeline of book publishing, such as creative activism, pamphlets, writing programmes in prisons, and other grassroots collaborative and participatory projects.

4. Risk the language of commonality. What, in fact, is the horizon of the long revolution? What kind of society are we working towards, with the understanding that utopia is not a realisable condition but a motivation to work against violences, large and small, that occur when the interests of property and capital override the value and dignity of people's lives? Williams's vocabulary initially seems an obstacle, given that his emphasis on the concept of social totality appears counteractive to the language of difference and identity which seems essential to a bicultural state. But "society" is never singular for Williams, but rather a set of smaller formations that interlock and interrelate in dynamic ways: "we have to explore new forms of variable societies, in which over the whole range of social purposes different sizes of society are defined for different kinds of issue and decision." 41 Defined in this manner, "society" carries over much of the resonance of "civil society," and the greater the variety of institutions, the richer the nature of social life. The actual forms of society are, in Williams's words, "close and specific to those who are living in and through them"-a language of social value that is far removed from the alienating image of society that was promoted within aesthetic modernism. ${ }^{42}$ Totality, for Williams, implies that local action is set within a larger structure: we don't understand the "reality of our immediate condition and the terms of change" without also "trying to grasp the process as a whole." Totality requires the participation of all people in society, and "thinking in terms of a totality is the realization that we are part of it; that our own consciousness, our work, our methods, are then critically at stake." ${ }^{\prime 3}$

So a dynamic sense of the interrelationship of past, present, and future - through the work of selective traditions - produces new common meanings, and these support a dynamic sense of society, where a multitude of particular interests are brought together to promote a larger general cause. As Williams himself observed in his discussion of Plan X people, the neoliberalism of the 1980s, too, had a vision of multiple points of decision-making and action, without the intervention of a top-down state; but it perverted these creative energies by seeing competition and the preservation of self-interest as the primary motivations for people's 
interactions. Williams's generations-long time scale is expansive, and so he does not offer solutions to the tensions of day-to-day politics, but rather returns us to the longer horizon; we don't want to fall into the trap, he says, of feeling "baffled by the insistent multiplicity of the present" and so making "long-term adjustments to short-term difficulties." 44 Ideas of modernity in crisis, or modernity as crisis, would seem counterproductive to Williams's mediating language, and his emphasis on the need for "the offering, reception, and comparison of new meanings" that "[lead] to the tensions and achievements of growth and change." ${ }^{45}$ In Aotearoa New Zealand, the creativity of selective tradition helps to build an alternative sense of modernity, an "alter-modernity," where the past is renewed through multiple lines of heritage and multiple avenues of interpretation, to safeguard a democratic future.

\footnotetext{
${ }^{1}$ Raymond Williams, Towards 2000 (London: Hogarth Press, 1983), 184.

${ }^{2}$ Conor Gearty, "Human Rights after Brexit: Still on Fantasy Island?" (lecture, London School of Economics, 8 December 2016).

3 "New Zealand's Prime Minister, Jacinda Adern, Is Young, Forward-Looking, and Unabashedly
} Liberal-Call Her the Anti-Trump," Vogue, 15 February 2018 [online].

https://www.vogue.com/article/jacinda-ardern-new-zealand-prime-minister-vogue-march-2018-issue

${ }^{4}$ For representative studies on these economic and social indicators, see: Max Rashbrook, ed., Inequality: A New Zealand Crisis (Wellington: Bridget Williams Books, 2013); Jane Kelsey, The FIRE Economy: New Zealand's Reckoning (Wellington: Bridget Williams Books with the New Zealand Law Foundation, 2015); Max Harris, The New Zealand Project (Wellington: Bridget Williams Books, 2017); and numerous articles and books chapters by Tracey McIntosh on racist justice and incarceration practices for Māori and other indigenous groups. For a general study of a decline in social trust in the Anglophone world, see Christian Albrekt Larsen, The Rise and Fall of Social Cohesion: The Construction and De-Construction of Social Trust in the US, UK, Sweden and Denmark (Oxford: Oxford University Press, 2013).

${ }^{5}$ Raymond Williams, The Long Revolution (Harmondsworth, Eng.: Pelican, 1965), 10. First published in 1961.

${ }^{6}$ Ibid, 10.

${ }^{7}$ Ibid, 383.

${ }^{8}$ Raymond Williams, Politics and Letters: Interviews with New Left Review (London: NLB, 1979), 144.

${ }^{9}$ Williams, The Long Revolution, 54.

${ }^{10}$ Ibid, 54 .

${ }^{11}$ Ibid, 76, 69.

${ }^{12}$ Ibid, 349, 362.

${ }^{13}$ Williams, Towards 2000, 245.

${ }^{14}$ Ibid, 152.

${ }^{15}$ Ibid, 245.

${ }^{16}$ Ibid, 245.

${ }^{17}$ Ibid, 127.

${ }^{18}$ Ibid, 258.

${ }^{19}$ For an extended discussion of the reasons for tolerance of relatively high corporate taxation during the middle decades of the twentieth century, see Kenneth Scheve and David Stasavage, Taxing the

Rich: A History of Fiscal Fairness in the US and Europe (Princeton, NJ: Princeton University Press, 2016). The authors analyse a range of economic and historical factors and conclude that the primary factors were the demands of funding war and the expectation that corporations will make sacrifices equivalent to those of the general population.

20 "The Politics of Hope: An Interview," in Raymond Williams: Critical Perspectives, ed. Terry Eagleton (Cambridge, UK: Polity, 1989), 176-83. 
${ }^{21}$ See Steven Levitsky and Daniel Ziblatt, How Democracies Die (New York: Crown, 2018). Freedom House reports annually on the state of global democracy and reported in 2017 that democracy has tracked 12 years of successive decline across the globe.

${ }^{22}$ Williams's selection of terms for Keywords, his extended semantic inquiry into what he saw as the crucial terms of debate for social theory and practice, gives some sense of where his emphasis lay. The terms "difference," "diversity," "pluralism" and "multiculturalism" do not appear, and "race" was added to the second edition only after criticism of its exclusion in the first edition. "Indigenous" is briefly tacked onto an (also brief) discussion of "native," and "colonialism" only appears through connection with the entry on "imperialism." Keywords: A Vocabulary of Culture and Society, revised edition (New York: Oxford UP, 1983). [First published 1976.] In Culture and Politics, interviewers from New Left Review press Williams on these and other omissions. As for the term "culture," which undergirds his entire oeuvre, Williams's response to the interviewers suggested that he had reached saturation point: "You know the number of times I've wished that I had never heard of the damned word. I have become more aware of its difficulties, not less, as I have gone on" (Politics and Letters, 154).

${ }^{23}$ Williams, "Tragedy and Revolution," in The Raymond Williams Reader, ed. John Higgins (Oxford UK: Blackwell, 2001), 96. [Extract first published in 1966.]

${ }^{24}$ Witi Ihimaera, "The Singing Word: Witi Ihimaera Interviewed by Juniper Ellis," Journal of Commonwealth Literature 34 (1999): 174-75.

${ }^{25}$ Williams, "Culture is Ordinary," in The Raymond Williams Reader, edited by John Higgins (Oxford, UK: Blackwell, 2001), 20. [Article first published in 1958.]

${ }^{26}$ See, for example, Helen Moewaka Barnes, Belinda Borell, and Tim McCreanor, "Theorising the Structural Dynamics of Ethnic Privilege in Aotearoa: Unpacking 'This Breeze at my Back,'” International Journal of Critical Indigenous Studies 7, no. 1 (2014).

${ }^{27}$ Williams, The Long Revolution, 53.

${ }^{28}$ Williams, Towards 2000, 141.

${ }^{29}$ Ibid, 246-47.

${ }^{30}$ I elaborate on this point in an extended reading of Robert Chapman's seminal article relating class analysis to realism as a literary form in my article "Revisiting 'Fiction and the Social Pattern' in the Era of Social Death: Materialising Recent New Zealand Literary History," JNZL: Journal of New Zealand Literature 31, no. 2 (2014): 95-121.

${ }^{31}$ Erin Mercer provides a comprehensive survey of departures from realism in her book Telling the Real Story: Genre and New Zealand Literature (Wellington: Victoria University Press, 2017).

${ }^{32}$ Alison Shonkwiler and Leigh Claire La Berge, "Introduction: A Theory of Capitalist Realism," in Reading Capitalist Realism, ed. Shonkwiler and La Berge (Iowa City: University of Iowa Press, 2014), 8 .

${ }^{33}$ Ibid, 9.

${ }^{34}$ Ibid, 7.

${ }^{35}$ Williams, "Tragedy and Revolution," in The Raymond Williams Reader, edited by John Higgins (Malden, MA: Blackwell, 2001), 99.

${ }^{36}$ Williams, Towards 2000, 141.

${ }^{37}$ See: Jack Ross, "The Time of Achamoth: M. K. Joseph and the Rise of New Zealand Speculative Fiction," JNZL 34, no. 2 (2016): 61-80; Dougal McNeill, "Rediscovering Utopias," Counterfutures 1 (2016): 15-36. McNeill offers four possible reasons for the "drying up" of Utopia as a genre in midtwentieth-century New Zealand: "the (relative) social peace and economic growth of the post-war period"; the hostility of classical Marxism towards the Utopian impulse; Māori demands for tino rangatiratanga, which asserts that Aotearoa is already a "somewhere" and hence not a blank slate for settler projections; and the advent of neoliberal reform, which "decomposed and disarticulated the organisational structures necessary for the kind of social dreaming Utopia requires" (20-23).

${ }^{38}$ Dougal McNeill, "Rediscovering Utopias," 29. Williams envisages the continuation of a utopian impulse through both the prevalence of dystopia as a literary form, and the real-life dystopia that is the "crisis of war and waste" under capitalist domination: see "Utopia and Science Fiction," in Problems in Materialism and Culture: Selected Essays (London: Verso, 1980), 196-212.

${ }^{39}$ Charles Crothers, "Appendix: The New Zealand Literature on Social Class/Inequality," New Zealand Sociology 28 no. 3 (2013): 255-89.

Journal of New Zealand Studies NS26 (2018), 5-17 https://doi.org/10.26686/jnzs.v0iNS26.4838 
${ }^{40}$ For representative examples, see: New Working-Class Studies, edited by John Russo and Sherry Lee Linkon (DigitalCommons@ILR, Cornell University, 2005); Barbara Korte and Georg Zipp, Poverty and Contemporary Literature: Themes and Figurations on the British Book Market (Houndmills, UK: Palgrave Macmillan, 2014).

${ }^{41}$ Williams, Towards 2000, 198.

${ }^{42}$ Ibid, 179.

${ }^{43}$ Williams, "Literature and Sociology," in Problems in Materialism and Culture: Selected Essays (London: Verso, 1997), 21.

${ }^{44}$ Williams, The English Novel from Dickens to Lawrence (London: Vintage, 1971), 150.

${ }^{45}$ Williams, The Long Revolution, 55. 